\title{
Antibiotic therapy as an adjunct to scaling and root planing in smokers: a systematic review and meta-analysis
}

\section{Naida Zanini ASSEM(a) \\ Márcio Luiz Ferro ALVES(a) \\ Alessandra Barreto LOPES(a) \\ Erivan Clementino GUALBERTO JUNIOR(a) \\ Valdir Gouveia GARCIA ${ }^{(b)}$ \\ Letícia Helena THEODORO(a)}

(a) Universidade do Estado de São Paulo Unesp, School of Dentistry, Department of Surgery and Integrated Clinic, Araçatuba, SP, Brazil.

(b) Latin American Institute of Dental Research and Education - Ilapeo, Curitiba, PR, Brazil.

Declaration of Interest: The authors certify that they have no commercial or associative interest that represents a conflict of interest in connection with the manuscript.

Corresponding Author:

Leticia Helena Theodoro

letheodoro@foa.unesp.br

ht1ps://doi.org/10.1590/1807-3107BOR-2017.vol31.0067

Submitted: Oct 6, 2016

Accepted for publication: Apr 27, 2017

Last revision: June 02, 2017

\begin{abstract}
The aim of this study was to perform a systematic review and meta-analysis to examine the effect of systemic antibiotics in the periodontal treatment of smokers. The selection criteria were as follows: controlled randomized clinical trials; studies published in English; studies with smoker patients diagnosed with chronic periodontitis; patients without systemic diseases; studies that used systemic antibiotic therapy associated with periodontal treatment; studies that presented results for the test and control groups and assessments of clinical periodontal parameters, such as probing depth (PD), bleeding on probing (BOP), and clinical attachment level (CAL). The differences in average weights were calculated with a confidence interval (CI) of 95\% for PD reduction, CAL gain and BOP. The means of the periodontal clinical parameters were compared between the baseline and post-treatment periods between the test groups and the control groups. The heterogeneity was assessed using the Cochran $Q$ test $(\mathrm{Q}(\mathrm{df}=3), \alpha=5 \%)$. A total of 67 articles were found, and after the selection process, three randomized controlled trials were included in the meta-analysis. The results indicate that SRP associated with systemic antibiotics promoted additional benefits when compared to SRP alone, with a greater reduction of PD $(p=0.0359, \mathrm{CI}=-0.42,-0.01)$ and a gain of CAL $(\mathrm{p}=0.0161, \mathrm{CI}=-0.39,-0.04)$. There was a modest $\mathrm{PD}$ reduction (PD, DM -0.21) and a modest CAL gain (CAL, DM -0.22). The results of our meta-analysis reveal the clinical benefits of systemic antibiotics as an adjunct to the non-surgical periodontal treatment of smokers. These clinical improvements, although statistically significant, appeared to be of little clinical relevance.
\end{abstract}

Keywords: Anti-Bacterial Agents; Dental Scaling; Smoking; Periodontitis.

\section{Introduction}

The association between smoking and periodontal health has been described in clinical and epidemiological studies, ${ }^{1,2}$ and these studies suggest that products derived from tobacco combustion can modify the clinical characteristics and progression of periodontal disease. Cigarettes have also been shown to be the major risk factor in the prevalence, extent, and severity of periodontal diseases. ${ }^{3,4,5,6}$ Some studies have demonstrated the possible absorption of nicotine by the root surfaces of smokers with periodontal disease. ${ }^{78}$ In addition, fibroblasts that were exposed to nicotine 
showed reduced proliferation, migration, and adhesion to the root surface and developed surface receptors that allowed the binding and internalization of nicotine in the cytoplasm. ${ }^{9} 10$ These changes damage cellular metabolism, as verified by reduced protein secretion and the synthesis of collagen fibers in these cells. ${ }^{11}$

Studies showed that the hemorrhagic responsiveness of the periodontium is suppressed by smoking. 12,13 There is a chronic reduction in blood flow and gingival crevicular fluid. ${ }^{14}$ Nicotine can increase the degradation of collagen fibers by fibroblasts, ${ }^{15}$ thus reducing the production of collagen. The decreased local oxygen tension in the subgingival environment and bacterial adhesion to epithelial cells caused by tobacco promotes the growth of anaerobic periodontal pathogens. ${ }^{11}$

Several studies have shown that smokers may be more colonized by certain periodontal pathogens than nonsmokers. ${ }^{16,17,18,19,20}$ However, other authors have not found this association. ${ }^{21,22,23}$ It has also been shown that smokers have less favorable responses to non-surgical and surgical periodontal therapy than nonsmokers. ${ }^{24,25,26,27,28,29}$

The treatment of periodontal disease is based on the elimination of pathogens through subgingival scaling and root planing (SRP). ${ }^{30}$ However, the use of only mechanical therapy may not be effective in eliminating these bacteria, which are often in areas inaccessible to periodontal instrumentation. ${ }^{31}$ Due to the moderate response of smokers to mechanical periodontal treatment, the use of adjunctive antimicrobials has been recommended. Some authors justify this use by claiming difficulties in eliminating subgingival pathogens in smokers with SRP. ${ }^{32,33,34}$

Although there is substantial evidence for the benefits of systemic antibiotic therapy in the treatment of periodontitis in general, ${ }^{35,36,37}$ few controlled studies have evaluated the effectiveness of periodontal treatment with adjunctive systemic antibiotics in smokers, $38,39,40,41,42,43,44,45$ and the differential benefit of specific forms of periodontal therapy in smokers remains unclear. Given these facts, there is currently no consensus on the use of systemic antibiotics for the periodontal treatment of smokers. Thus, the aim of this study is to conduct a systematic review and meta-analysis to evaluate the effectiveness of systemic antibiotic therapy associated with periodontal treatment in smokers.

\section{Methodology}

This meta-analysis was conducted according to the Cochrane Collaboration ${ }^{46}$ and by following the principles of the Preferred Reporting Items for Systematic Reviews and Meta-analysis, or Prisma. ${ }^{47}$ The selected focused question was: "Do adjunctive antimicrobials improve the clinical outcome of non-surgical therapy (scaling and root planing [SRP]) in the treatment of periodontitis in smokers?"

\section{Search strategy}

Research was carried out to identify randomized controlled clinical studies using systemic antibiotic therapy in the periodontal treatment of smokers. The following keywords were searched: ("periodontitis" [MeSH Terms] OR "periodontitis" [All Fields]) AND ("anti-bacterial agents" [MeSHTerms] OR ("anti-bacterial" [All Fields] AND “agents" [All Fields]) OR "anti-bacterial agents" [All Fields] OR ("anti" [All Fields] AND "bacterial" [All Fields] AND "agents" [All Fields]) OR "antibacterial agents" [All Fields] OR "anti-bacterial agents" [Pharmacological Action]) AND ("smoking" [MeSH Terms] OR "smoking" [All Fields]) AND "periodontal" [All Fields] AND ("therapy" [Subheading] OR "therapy" [All Fields] OR "therapeutics" [MeSH Terms] OR "therapeutics" [All Fields]). Databases were searched from July 1994 to August 2016. The included databases were MEDLINE, Cochrane Controlled Clinical Trial Register, Cochrane Database of Systematic Reviews, Database of Abstracts of Reviews of Effects, CINAHL, Science Direct, and ISI Web of Knowledge and Scopus. In addition, we searched previous review articles on the subject as well as the reference lists of the identified articles for potentially relevant publications.

\section{Study selection}

Articles were selected by two blinded reviewers (NZ and MF). In cases where the reviewers disagreed, there was a discussion between them. If no consensus was reached, a third reviewer (LHT) was involved. The selection criteria were as follows: a) controlled randomized clinical trials; b) studies published in English; c) studies with smoker patients (at least 10 cigarettes per day for at least five years) diagnosed with chronic periodontitis; d) patients without 
systemic diseases (such as diabetes, HIV status, etc.); e) patients with ages between 30 and 70 years old; f) patients with a lack of medical disorders that required antibiotic prophylaxis; g) patients who did not receive periodontal treatment in the last six months; h) studies that used systemic antibiotic therapy associated with periodontal treatment; i) studies that present the results of the test and control groups, and j) assessments of clinical periodontal parameters, such as probing depth (PD), bleeding on probing (BOP) and clinical attachment level (CAL). Exclusion criteria were studies on local antibiotic therapy and those that were not published in English.

\section{Clinical variables}

CAL gain and PD reduction were the primary outcomes of interest. CAL gain was defined as the difference between the CAL level measurements at baseline and at final evaluation in each study. Likewise, PD reduction was defined as the difference between the baseline and final recordings. BOP was a secondary variable. BOP change was defined as the difference between the percentages at baseline and at the final evaluation.

\section{Data extraction}

In addition to the clinical variables, the following data were extracted: the year of publication, country, study design, medication dosage, number of participants, demographic characteristics, length of follow-up, and adverse effects. Only the accepted numerical clinical data are presented in the tables and text. Two reviewers (NZ and MF) independently extracted all data. Conflicting data were reviewed to reach a consensus.

\section{Quality of studies}

An analysis of the quality of the studies was performed by two reviewers (NZ and MF) by distributing scores of 0 or 1 for each category of studies, following the Jadad Scale: ${ }^{48}$ (a) if there is description of randomization; $b$ ) if there is a description of blinding; c) if there is a description of losses to follow-up; d) if the randomization is inappropriate or appropriate; and e) if the blinding is inappropriate or appropriate. A study that had a total score $<3$ was considered an inadequate study.

\section{Quantitative analysis}

Effect size measures

To conduct the meta-analysis, the data were combined using the software R 3.1.1 (R Foundation for Statistical Computing, Vienna, Austria). The effect size was estimated and reported as the mean difference (MD) with $95 \%$ confidence intervals (CI). The combined effect was considered significant if $\mathrm{p}<0.05$. For each variable, a meta-analysis was performed, as represented by the Forest plots (mean, standard deviation, and sample size). Each study yielded an average (shown as blocks) and its confidence intervals (CI) (shown as lines). Statistical heterogeneity $\left(\mathrm{I}^{2}\right)$ was calculated using the total number of participants per group, overall effect of the average (MD and the statistic $\mathrm{Z}$ ) in the random effect model, and percentage of weight given to each study.

\section{Heterogeneity}

Heterogeneity was assessed by the chi-squared-based $Q$-statistic method and $I^{2}$ measurement with significance indicated by $\mathrm{p}<0.05$.

\section{Publication bias}

Bias was investigated for each result by two methods: a) visual detection was used to analyze the funnel plot $^{49}$ and b) regression analysis was performed by an asymmetry test. ${ }^{50}$

\section{Results}

\section{Search strategy}

A total of 68 articles were found (MEDLINE $=67$ articles, Cochrane Library $=1$ article), and the one study found in Cochrane was repeated in MEDLINE. Of these unique articles (67), 46 articles were excluded because they were not performed with smokers. Of the remaining 21, nine publications were performed with systemic antimicrobial/antibiotic therapy. After an analysis of these nine articles (Table 1$)^{38,39,40,41,42,43,44,45,51}$ by the two reviewers, only four studies were included because they were randomized controlled trials that evaluated the effects of systemic antibiotics in smokers with chronic periodontitis (Figure 1). To characterize 
Table 1. Studies selected by reading the title and abstract, main findings related to the use of systemic antibiotics, and reasons for exclusion ( $\mathrm{n}=9$ ).

\begin{tabular}{|c|c|c|}
\hline Study (year) & Reason for exclusion & Main findings \\
\hline Faveri et al. (2014) & $\begin{array}{l}\text { Did not compare control group (SRP) vs. } \\
\text { treatment group. }\end{array}$ & $\begin{array}{l}\text { Smokers with SRP }+ \text { AMX }+M T Z \text { show less favorable clinical and } \\
\text { microbiologic outcomes than non-smokers. }\end{array}$ \\
\hline Matarazzo et al. (2008) & Included. & $\begin{array}{l}\text { The greatest benefits in clinical and microbiological parameters are } \\
\text { achieved with the use of SRP }+M T Z+A M X \text {. }\end{array}$ \\
\hline Dastoor et al. (2007) & Included. & $\begin{array}{l}\text { The adjunctive administration of systemic } A Z M \text { to surgical treatment } \\
\text { did not improve overall PD reduction or } C A L \text { gain. }\end{array}$ \\
\hline Needleman et al. (2007) & Included. & $\begin{array}{l}\text { No differences were observed for absolute change in clinical or } \\
\text { biochemical markers at } 6 \text { months. }\end{array}$ \\
\hline Pahkla et al. (2006) & $\begin{array}{l}\text { Did not compare control group (SRP) vs. } \\
\text { treatment group. }\end{array}$ & $\begin{array}{l}\text { AMX and MTZ for } 7 \text { days were effective in non-smoking and } \\
\text { smoking patients. }\end{array}$ \\
\hline Mascarenhas et al. (2005) & $\begin{array}{l}\text { Absence of original standard deviation } \\
\text { values. }\end{array}$ & $\begin{array}{l}\text { The results demonstrated that both groups displayed clinical } \\
\text { improvements in PD and CAL that were sustained for } 6 \text { months. }\end{array}$ \\
\hline Söder et al. (1999) & Treatment of residual pockets. & $\begin{array}{l}\text { Smokers responded less favorably than non-smokers to periodontal } \\
\text { therapy. An intervention group of smokers did not show significantly } \\
\text { reduced PD and CAL. }\end{array}$ \\
\hline Palmer et al. (1999) & $\begin{array}{l}\text { Their clinical results evaluated only sites } \\
\text { with } P D \geq 4.6 \mathrm{~mm} \text {. }\end{array}$ & $\begin{array}{l}\text { There were no differences in any clinical measures in response to the } \\
\text { three treatment regimens (SRP, SRP }+M T Z, S R P+\text { Local MTZ) at } 2 \text { or } 6 \\
\text { months for either smokers or non-smokers. }\end{array}$ \\
\hline Preus et al. (2014) & $\begin{array}{l}\text { Absence of original data of smoker } \\
\text { patients in each control and test group. }\end{array}$ & $\begin{array}{l}\text { Current smokers benefited more from treatment than former or never } \\
\text { smokers. Both sets of results are likely to be biased with respect to } \\
\text { validity of conclusion regarding causal effects of smoking. }\end{array}$ \\
\hline
\end{tabular}

chronic periodontitis, we considered adult patients, aged $\geq 30$ years, with loss of $\geq 5 \mathrm{~mm}$ CAL, with $30 \%$ of sites with PD and CAL $\geq 4 \mathrm{~mm}$ and bleeding on probing. The smoker patients should smoke at least 10 cigarettes per day for at least five years. The selected studies used the following systemic antibiotics: azithromycin (AZM) ${ }^{40,42}$ doxycycline (DOX), ${ }^{43}$ and a combination of metronidazole (MTZ) with amoxicillin (AMX) ${ }^{44}$

Among these four selected articles, two presented only mean data and standard deviations. After communication via email to the authors, only one corresponding author sent us the detailed results of his study. ${ }^{43}$ Given this, one study was excluded for not having access to the numerical data of the standard deviation of the differences. ${ }^{40}$ One of the articles was divided into two studies (study 1 and 2), and it compared two treatments using different systemic antibiotics with a placebo group. ${ }^{44}$ Thus, the meta-analysis was performed using three $\operatorname{articles}^{42,43,44}$ and four trials (Table 2).

\section{Description of Studies}

The study by Matarazzo et al. ${ }^{44}$ observed significant advantages in clinical and microbiological parameters by using antibiotics. In group A, SRP was associated with MTZ (400 mg) and AMX (500 mg) t.i.d. In group B, SRP was associated with MTZ (400 mg) and a placebo t.i.d. In group C, SRP was associated with two placebos ( $3 x$ daily for 14 days). Patients who received SRP+MTZ+AMX (group A) showed the greatest PD reduction and greatest CAL gain (PD: $4.0 \mathrm{~mm}$ to $3.0 \mathrm{~mm}$ from baseline to 3 months; CAL from $4.8 \mathrm{~mm}$ to $3.9 \mathrm{~mm}$ ); SRP+MTZ (group B) baseline: $3.7 \mathrm{~mm}(\mathrm{PD})$, 3 months: $2.9 \mathrm{~mm}$ (PD), baseline: $4.5 \mathrm{~mm}$ (CAL), three months: $3.9 \mathrm{~mm}$ (CAL); and SRP (Group C) baseline: $3.9 \mathrm{~mm}$ (PD); three months: $3.3 \mathrm{~mm}$ (PD), baseline: $4.7 \mathrm{~mm}$ (CAL), three months: $4.2 \mathrm{~mm}$ (CAL). Both groups with antibiotic therapy had a greater reduction in the percentage of sites with BOP compared to Group C ( $p<0.01)$. The microbiological evaluation revealed a reduction in the average count of red complex ${ }^{52}$ pathogens (Tannerella forsythia, Treponema 


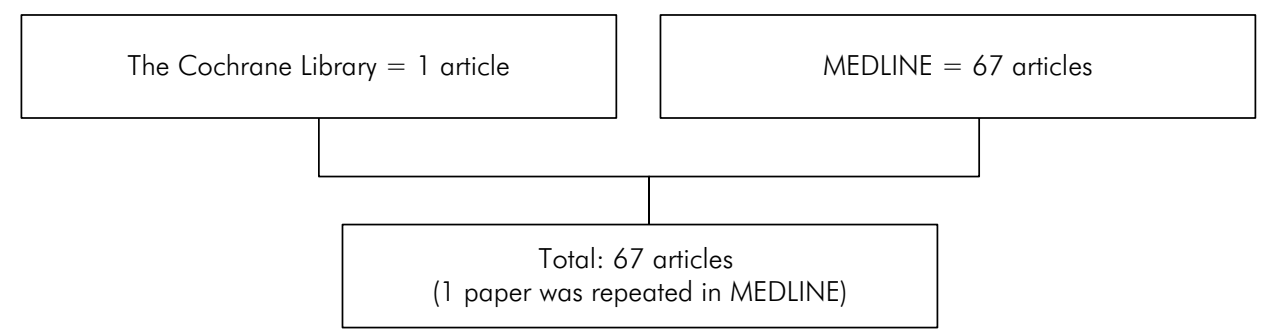

\begin{tabular}{|l|l|}
\hline $\begin{array}{c}46 \text { articles excluded because } \\
\text { they were not made with smokers }\end{array}$ & $\begin{array}{c}9 \text { articles were selected by reading the title } \\
\text { and abstracts - related of the use of systemic antibiotics }\end{array}$ \\
\cline { 2 - 3 }
\end{tabular}

Final decision: 4 artices were included

(controlled randomized clinical trials)

Figure 1. Flow chart of research.

Table 2. Studies listed in meta-analysis.

\begin{tabular}{|c|c|c|c|c|}
\hline Author/Study & Country & Study design & Patients & Treatment \\
\hline $\begin{array}{l}\text { Matarazzo et al. (2008) } \\
\text { Study } 1\end{array}$ & Brazil & $\begin{array}{l}\text { Parallel, double-blinding, } \\
\text { control placebo }\end{array}$ & $\begin{array}{c}43 \text { (CP) } \\
\text { Test group: } 14\end{array}$ & SRP + MTZ (400 mg) 3x daily for 14 days \\
\hline $\begin{array}{l}\text { Matarazzo et al. (2008) } \\
\text { Study } 2\end{array}$ & Brazil & $\begin{array}{l}\text { Parallel, double-blinding, } \\
\text { control placebo }\end{array}$ & $\begin{array}{c}43 \text { (CP) } \\
\text { Test group: } 14\end{array}$ & $\begin{array}{c}\mathrm{SRP}+\mathrm{MTZ}(400 \mathrm{mg})+\mathrm{AMX}(500 \mathrm{mg}) \\
\text { 3x daily for } 14 \text { days }\end{array}$ \\
\hline $\begin{array}{l}\text { Dastoor et al. (2007) } \\
\text { Study } 3\end{array}$ & USA & $\begin{array}{l}\text { Parallel, double-blinding, } \\
\text { control placebo }\end{array}$ & $\begin{array}{l}30(\mathrm{CP}) \\
\text { Test group: } 15\end{array}$ & $\begin{array}{c}\text { SRP }+ \text { Azithromycin }(500 \mathrm{mg}) 1 \times \text { daily for } \\
3 \text { days }\end{array}$ \\
\hline $\begin{array}{l}\text { Needleman et al. (2007) } \\
\text { Study } 4\end{array}$ & United Kingdom & $\begin{array}{l}\text { Parallel, double-blinding, } \\
\text { control placebo }\end{array}$ & $\begin{array}{l}30(\mathrm{CP}) \\
\text { Test group: } 16\end{array}$ & $\begin{array}{c}\text { SRP + Doxycycline }(20 \mathrm{mg}) 2 x \text { daily for } \\
3 \text { months }\end{array}$ \\
\hline
\end{tabular}

CP: chronic periodontitis; SRP: scaling and root planing; MTZ: metronidazole; AMX: amoxicillin.

denticola, and Porphyromonas gingivalis) in all groups, with no significant reduction in Group C. The mean counts of some putative periodontal pathogens in the orange complex also had a significant reduction in Group (B) (Campylobacter rectus, Eubacterium nodatum, and Parvimonas micra) and in Group (A) (E. nodatum, Fusobacterium nucleatum, and P. polymorphum micra). Although there was no statistically significant difference in Group C, after three months of SRP, an increase was noted for all four species of Fusobacterium. Levels of most purple, yellow, blue and green complex ${ }^{52}$ pathogens and Actinomyces species were minimally affected by the different treatments.

In both studies with AZM, treatments with and without systemic antibiotics yielded improvements in clinical parameters among heavy smokers $(p<0.05)^{40,42}$ The study included in the meta-analysis ${ }^{42}$ demonstrated a statistically significant reduction of $\mathrm{PD}$ in both the test group (SRP + AZM $500 \mathrm{mg}$ for three days) and the control group (SRP + placebo) at six months compared to baseline (PD: $-0.27 \mathrm{~mm}$ and $-0.39 \mathrm{~mm}$, respectively). Only the test group showed a statistically significant mean CAL gain $(-0.27 \mathrm{~mm})$. However, there was no statistically significant difference between the groups in any period for PD or CAL. Another study, ${ }^{40}$ in which the patients in the test group received AZM for five days (two 250-mg tablets on day 1 and one 250-mg tablet daily for the next four days), revealed a statistically significant difference in CAL gain and $\mathrm{PD}$ reduction in both test groups $(1.13 \mathrm{~mm}$ and 1.33 $\mathrm{mm}$, respectively) and in the control $(0.46 \mathrm{~mm}$ and $0.45 \mathrm{~mm}$, respectively) at six months compared to the baseline $(\mathrm{p}<0.05)$. In deep sites (PD $>6 \mathrm{~mm}$ ), patients in the test group showed a greater $P D$ 
reduction compared to the control group (3.52 $\mathrm{mm}$ vs. $1.98 \mathrm{~mm}, \mathrm{p}<0.05)$, and there was a higher CAL gain $(2.56 \mathrm{~mm}$ vs. $1.32 \mathrm{~mm}, \mathrm{p}<0.05)$ at six months.

Another study ${ }^{43}$ compared the association of SRP with low-dose DOX (20 mg, two times a day for three months) with SRP and a placebo and showed no statistically significant differences in clinical parameters between the test and control groups (average PD reduction: $-1.40 \mathrm{~mm}$ vs. $-0.98 \mathrm{~mm}$; CAL average gain: $-0.65 \mathrm{~mm}$ vs. $-0.40 \mathrm{~mm}$ ) at six months.

\section{Risk of bias}

There was no disagreement between the reviewers in assessing and evaluating the quality of the studies. All of the studies included in the meta-analysis ${ }^{42-44}$ showed a low risk of bias, with a score of 3 or 4 .

\section{Intervention effect}

All studies included in the meta-analysis were randomized controlled trials with a parallel study design. All studies had a control group using a placebo and double-blinding. The differences in average weights, with a confidence interval of $95 \%(95 \% \mathrm{CI})$, enabled the following parameters to be calculated: PD reduction, CAL gain, and BOP. The meta-analysis showed that there was a statistically significant PD reduction in favor of systemic antibiotics $(-0.21 \mathrm{~mm}$ vs. $-0.42 \mathrm{~mm}$ MD, $\mathrm{p}<0.05$; Figure 2). Additionally, there was a statistically significant CAL gain $(-0.22 \mathrm{~mm}$ vs. $-0.39 \mathrm{~mm} \mathrm{MD}, \mathrm{p}<0.05$; Figure 3 ) in favor of antibiotics. However, there was no statistically significant difference in BOP between treatments $(-4 \%$ vs. $-0.13 \% \mathrm{MD}, \mathrm{p}>0.05$; Figure 4$)$. The outcomes for $\mathrm{PD}$ and CAL were more homogeneous $(\mathrm{Q} P D(\mathrm{df}=3)$ 8.3866; $\mathrm{p}=0.0387$; Figure 2, and Q CAL $(\mathrm{df}=3) 1.4536$; $\mathrm{p}=0.6930$; Figure 3$)$, and for BOP (Q BOP $(\mathrm{df}=3)$ 27.6420; $\mathrm{p}<0.0001$; Figure 4).

\section{Publication bias}

Visual inspection and quantitative analysis revealed no evidence of bias in publications for PD and CAL.

\section{Discussion}

The results of this meta-analysis support the effectiveness of the adjunctive use of systemic antibiotics in the treatment of chronic periodontitis in smokers, as the results showed that systemic antibiotic therapy favors clinical attachment gain and PD reduction, even though it did not lead to a reduction in BOP when compared to the SRP-treated groups and the placebo. However, the major limitation of this meta-analysis is the existence of few controlled randomized clinical trials for smokers. On the other hand, other recent meta-analysis demonstrated that

\begin{tabular}{l}
\hline Test for heterogeneity: \\
\hline$Q(d f=3)=8.3866$ \\
\hline$p-v a l=0.0387$ \\
\hline zval $=-2.0976$ \\
\hline pval $=0.0359$ \\
\hline
\end{tabular}

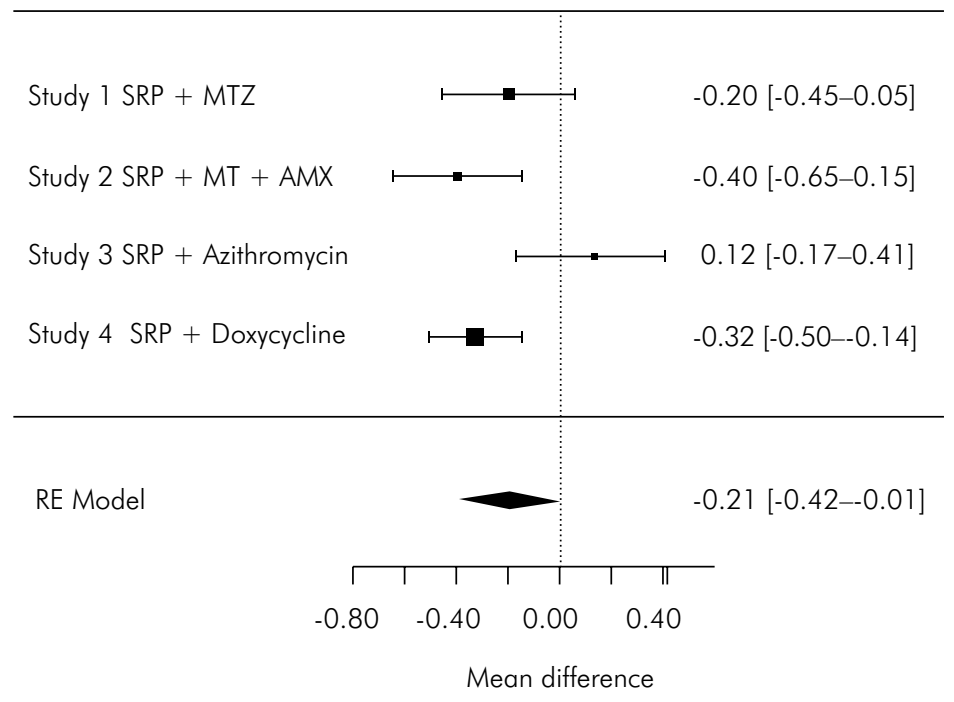

Figure 2. Forest plot for PD. 


\begin{tabular}{l}
\hline Test for heterogeneity: \\
\hline$Q(d f=3)=1.4536$ \\
\hline$p-v a l=0.6930$ \\
\hline zval $=-2.4072$ \\
pval $=0.0161$ \\
\hline
\end{tabular}

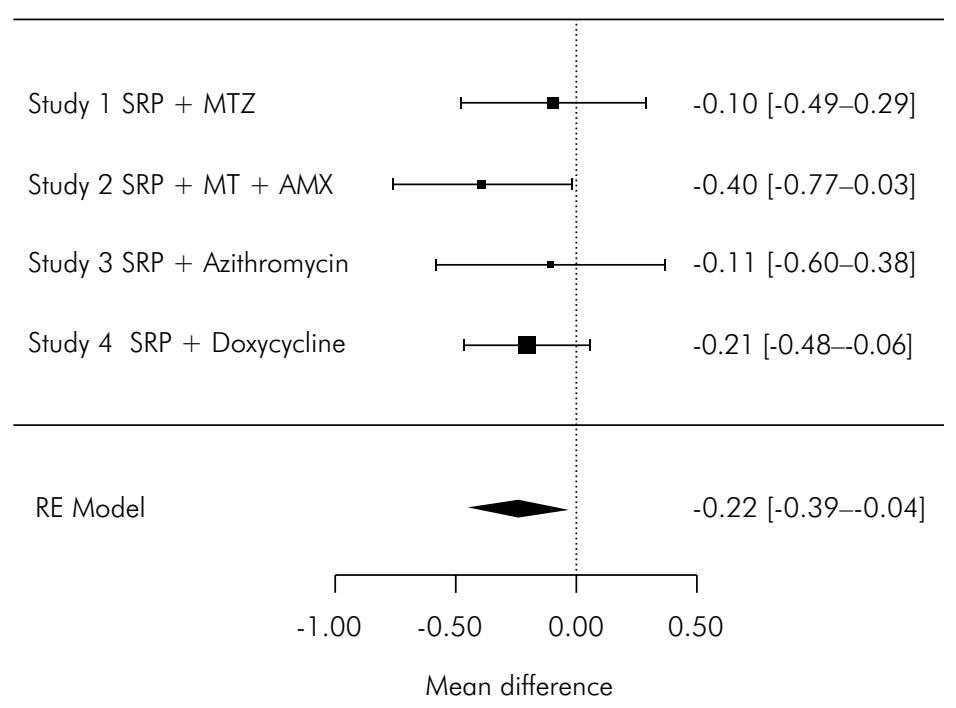

Figure 3. Forest plot for CAL.

\begin{tabular}{l}
\hline Test for heterogeneity: \\
\hline$Q(d f=3)=27.6420$ \\
\hline$p-v a l<0.0001$ \\
\hline zval $=-0.7621$ \\
\hline pval $=0.4460$ \\
\hline
\end{tabular}

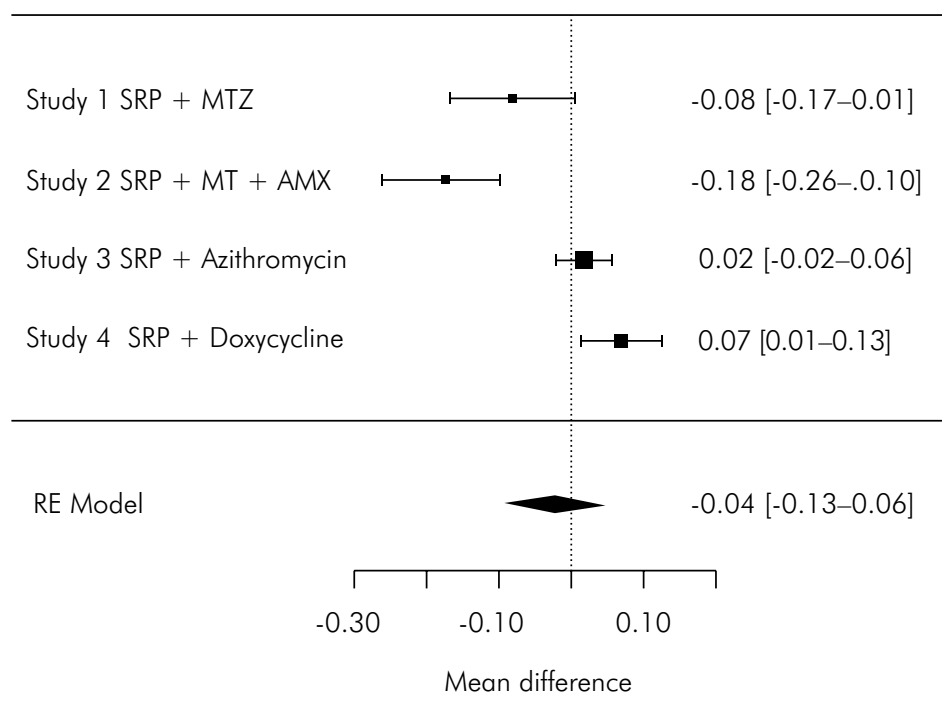

Figure 4. Forest plot for BOP.

in smokers with chronic periodontitis, adjunctive use of local antimicrobials improved the efficacy of non-surgical periodontal therapy in reducing $\mathrm{PD}$ and improving CAL at sites presenting PD $\geq 5$ $\mathrm{mm}$ before treatment. Moreover, evidence did not demonstrate similar gains when scaling and root planing plus systemic antibiotics were associated with therapy. ${ }^{53}$

In addition, it should be considered that despite the statistically significant difference in the reduction of PD and the gain in CAL in favor of the use of antibiotics, the results of this meta-analysis must be interpreted with caution because the data are means and, as such, may not be clinically relevant. There was a modest $\mathrm{PD}$ reduction (PD, DM -0.21) and a modest CAL gain (CAL DM -0.22). These clinical improvements, although statistically significant, appeared to be of little clinical relevance.

Regarding the methodological quality of the studies, the results showed that all the included studies had a low risk of bias. It should also be considered that the articles included in the meta-analysis presented two evaluation periods of six months ${ }^{42,43}$ and three months ${ }^{44}$ after treatment. 
The growing interest in defining the most effective periodontal therapy for smokers is related to the fact that this group of patients responds poorly to mechanical therapies, such as SRP. ${ }^{41,54}$ In the case of smokers, there is still no systemic antibiotic therapy accepted by a consensus because few studies have evaluated its effect as an adjunct to periodontal therapy ${ }^{40,42,43,44}$ and each study uses a different antibiotic. Several systemic antibiotics or antibiotic combinations have been used as an adjunct therapy in the treatment of chronic periodontitis, such as the use of AMX, MTZ, DOX, and AZM. ${ }^{35,26,37,55}$ For non-smokers, several studies have shown clinical benefits, such as a reduction of PD and a CAL gain, to using systemic antibiotic therapy associated with non-surgical therapy. ${ }^{56,57,58}$ However, the variability of dosing, frequency, time of use, and choice of antibiotics led to a consideration of the need to establish protocols for an effective therapy.

The use of an adjunctive therapy, such as MTZ or MTZ+AMX, is based on previous studies that suggested the clinical and microbiological benefits of these antibiotics, alone or in combination, in the treatment of chronic periodontitis among non-smoking patients ${ }^{56,57,58,59}$ and smokers. ${ }^{44}$

The use of AZM, which has been extensively evaluated as an adjunct to the treatment of periodontal disease because it has better oral absorption than other antibiotics, ${ }^{42}$ was evaluated in a meta-analysis of studies included here. That study ${ }^{42}$ examined AZM prescribed at a dose of one 500-mg tablet one time per day for three days. The results showed no benefit as an adjunct to surgical therapy for heavy smokers in terms of PD reduction and CAL gain (data not used in the meta-analysis), despite showing reduced plaque formation for up to three months, reduced signs of inflammation and a promotion of accelerated healing. However, for the areas receiving only non-surgical therapy (data used in this meta-analysis), the use of AZM promoted a significant gain in CAL compared to baseline, while there was no gain in the control group (SRP + placebo)

With the results of the included studies, we can consider that AZM, monotherapy with MTZ or MTZ combined with AMX has the potential to yield clinical benefits when used as adjuvant therapy to non-surgical periodontal treatment in smokers. When different antibiotics were compared in one study, a combination of AMX and MTZ was more effective than MTZ alone. ${ }^{44}$

A possible indication for the use of antibiotics in periodontal treatment could be smoking.$^{60}$ However, there is still no consensus on this statement because a larger number of randomized controlled trials with large sample sizes is needed. Two recent studies ${ }^{45,61}$ compared the effect of systemic antibiotics (MTZ+AMX) in smokers and non-smokers. The clinical and microbiological results showed that after three months, smokers responded less favorably than non-smokers. ${ }^{45}$ However, linear regression analysis of the reduction in the number of sites with PD $>4 \mathrm{~mm}$ and BOP revealed that smokers benefitted more from the non-surgical treatment phase than non-smokers. ${ }^{61}$ Thus, smokers may have a specific advantage in being treated with MTZ+AMX in the non-surgical phase.

A result that deserves attention in the quantitative analysis of this meta-analysis is the fact that there was no significant difference in the reduction of BOP in smokers treated with antibiotics. These results can be explained by the vasoconstrictive action of nicotine, which masks the classic signs of acute gingival inflammation in periodontal disease. ${ }^{12,13}$ Thus, less BOP in smokers compared to nonsmokers leads us to believe that, regardless of therapy, this clinical parameter is inherently altered by smoking.

In the microbiological analysis, only one of the included studies conducted molecular analysis using checkerboard DNA-DNA hybridization, so this analysis was not included in the quantitative analysis of the meta-analysis. ${ }^{44}$ The same study showed that the combination of MTZ+AMX produced greater beneficial changes in the subgingival microbiota, such as a significant reduction in the mean score and the proportion of periodontal pathogens, such as T. forsythia, P. gingivalis, and T. denticola, and an increase in the proportion of beneficial species, especially blue and purple complexes (A. israelii, A. odontolyticus, and Veillonella parvula).

Another included study ${ }^{42}$ assessed the presence of some bacterial species through the BANA test, which 
has high sensitivity and specificity for the presence of red complex bacteria (T. forsythia, P. gingivalis, and T. denticola) and the presence of the ICTP (cross-linked telopeptide of type I collagen), a marker of bone resorption in the crevicular fluid. For the group of samples not treated with AZM at three months, they returned to the same levels as baseline and differed from the group treated with AZM, which maintained a reduction of labeled bacteria in the BANA test. The use of AZM did not cause a reduction in the levels of ICTP.

Given these results, another advantage of antibiotic use associated with conventional mechanical treatment for smokers could be the decreased need for retreatment, which would reduce the cost compared to repeated episodes of treatment. Repeated SRP treatments can promote greater damage to mineralized dental tissues and can produce greater gingival recession. Even though mechanical treatment does not predictably eliminate all bacteria from disease sites, a restrictive attitude towards using antibiotics has been recommended in view of the increasing development of global antibiotic resistance. ${ }^{62}$

\section{References}

1. Bergström J, Preber H. Tobacco use as a risk factor. J Periodontol. 1994;65(5 Suppl):545-50. https://doi.org/10.1902/jop.1994.65.5.545

2. Bergström J. Periodontitis and smoking an evidence-based appraisal. J Evid Based. Dent Pract. 2006;6(1):33-41. https://doi.org/10.1016/i.jebdp.2005.12.018

3. Albandar JM. Global risk factors and risk indicators for periodontal diseases. Periodontol 2000. 2002;29(1):177-206. https://doi.org/10.1034/j.1600-0757.2002.290109.x

4. Oppermann RV. An overview of the epidemiology of periodontal diseases in Latin America. Braz Oral Res. 2007;21 Spec Iss 1:8-15. http://dx.doi.org/10.1590/S1806-83242007000500003

5. Stabholz A, Soskolne WA, Shapira L. Genetic and environmental risk factors for chronic periodontitis and aggressive periodontitis. Periodontol 2000. 2010;53(1):138-53. https://doi.org/10.1111/j.1600-0757.2010.00340.x

6. Johannsen A, Susin C, Gustafsson A. Smoking and inflammation: evidence for a synergistic role in chronic disease. Periodontol 2000. 2014;6(1)4:111-26. https://doi.org/10.1111/j.1600-0757.2012.00456.x
The main limitation of this review and meta-analysis was the inclusion of a small number of studies. The number of studies is limited, and we call for further randomized controlled trials to clarify controversies on the use of systemic antibiotics. This limitation should be considered when evaluating the results of this meta-analysis.

\section{Conclusion}

The findings of this meta-analysis reveal clinical benefits of the use of some systemic antibiotics as an adjunct to SRP for chronic periodontitis in smokers. However, given the limitations of this meta-analysis, the limited number of controlled randomized clinical trials in smokers, and the low level of clinical relevance of the meta-analysis results, no clinical recommendation can be made. To assess differential benefits, future studies should compare smokers with non-smokers within the same study and should compare different prescriptions. To have sufficient statistical power, such studies need to include larger numbers of participants.

7. McGuire JR, McQuade M, Rossmann J, Garnick JJ, Sutherland DE, Scheidt MJ et al. Cotinine in saliva and gingival crevicular fluid of smokers with periodontal disease. J Periodontol. 1989;60(4):176-81. https://doi.org/10.1902/jop.1989.60.4.176

8. Cuff MJ, McQuade MJ, Scheidt MJ, Sutherland DE, Van Dyke TE. The presence of nicotine on root surfaces of periodontally disease teeth in smokers J Periodontol. 1989;60(10):564-9. https://doi.org/10.1902/jop.1989.60.10.564

9. Hanes PJ, Schuster GS, Lubas S. Binding uptake and release of nicotine by human gingival fibroblasts. J Periodontol. 1991;62(2):147-52. https://doi.org/10.1902/jop.1991.62.2.147

10. Kinane DF, Chestnutt IG. Smoking and periodontal disease. Crit Rev Oral Biol Med. 2000;11(3):356-65. https://doi.org/10.1177/10454411000110030501

11. Mecklenburg RE, Grossi SG. Tobacco use and intervention. In: Rose LF, Genco RJ, Cohen DW, Mealey BL, editors. Periodontal medicine. Hamilton: Decker; 2000. p. 99-119.

12. Bergström J, Boström L. Tobacco smoking and periodontal hemorrhagic responsiveness. J Clin Periodontol. 2001;28(7):680-5. https://doi.org/10.1034/j.1600-051x.2001.028007680.x 
13. Dietrich T, Bernimoulin JP, Glynn RJ. The effect of cigarette smoking on gingival bleeding. J Periodontol. 2004;75(1):16-22. https://doi.org/10.1902/jop.2004.75.1.16

14. Morozumi T, Kubota T, Sato T, Okuda K, Yoshie H. Smoking cessation increases gingival blood flow and gingival crevicular fluid. J Clin Periodontol. 2004;31(4):267-72. https://doi.org/10.1111/j.1600-051X.2004.00476.x

15. Zhang W, Song F, Windsor LJ. Cigarette smoke condensate affects the collagen-degrading ability of human gingival fibroblasts. J Periodontal Res. 2009 Dec;44(6):704-13. https://doi.org/10.1111/j.1600-0765.2008.01179.x

16. Eggert FM, McLeod MH, Flowerdew G. Effects of smoking and treatment status on periodontal bacteria: evidence that smoking influences control of periodontal bacteria at the mucosal surface of the gingival crevice. J Periodontol. 2001 Sep;72(9):1210-20. https://doi.org/10.1902/jop.2000.72.9.1210

17. Haffajee AD, Socransky SS. Relationship of cigarette smoking to the subgingival microbiota.

J Clin Periodontol. 2001 May;28(5):377-88. https://doi.org/10.1034/i.1600-051x.2001.028005377.x

18. Winkelhoff AJ, Bosch-Tijhof CJ, Winkel EG, Reijden WA. Smoking affects the subgingival microflora in periodontitis. J Periodontol. 2001;72(5):666-71. https://doi.org/10.1902/jop.2001.72.5.666

19. Shchipkova AY, Nagaraja HN, Kumar PS. Subgingival microbial profiles of smokers with periodontitis. J Dent Res. 2010;89(11):1247-53. https://doi.org/10.1177/0022034510377203

20. Guglielmetti MR, Rosa EF, Lourenção DS, Inove G, Gomes EF, De Micheli $G$, et al. Detection and quantification of periodontal pathogens in smokers and never-smokers with chronic periodontitis by real-time polymerase chain reaction. J Periodontol. 2014;85(10):1450-7. https://doi.org/10.1902/jop.2014.140048

21. Boström L, Bergström J, Dahlén G, Linder LE. Smoking and subgingival microflora in periodontal disease. J Clin Periodontol. 2001;28(3):212-9. https://doi.org/10.1034/j.1600-051x.2001.028003212.x

22. Apatzidou DA, Riggio MP, Kinane DF. Impact of smoking on the clinical, microbiological and immunological parameters of adult patients with periodontitis. J Clin Periodontol. 2005;32(9):97383. https://doi.org/10.1111/j.1600-051X.2005.00788.x

23. Fritschi BZ, Albert-Kiszely A, Persson GR.

Staphylococcus aureus and other bacteria in untreated periodontitis. J Dent Res. 2008;87(6):589-93. https://doi.org/10.1177/154405910808700605

24. Preber H, Bergström J. Effect of cigarette smoking on periodontal healing following surgical therapy. J Clin Periodontol. 1990;17(5):324-28. https://doi.org/10.1111/j.1600-051X.1990.tb01098.x

25. Zambon JJ, Grossi SG, Machtei EE, Ho AW, Dunford R, Genco RJ. Cigarette smoking increases the risk for subgingival infection with periodontal pathogens. J Periodontol. 1996;67(10 Suppl):1050-4. https://doi.org/10.1902/jop.1996.67.10s.1050
26. Tonetti MS. Cigarette smoking and periodontal diseases: etiology and management of disease. Ann Periodontol. 1998;3(1):88-101. https://doi.org/10.1902/annals.1998.3.1.88

27. Labriola A, Needleman I, Moles DR. Systematic review of the effect of smoking on nonsurgical periodontal therapy. Periodontol 2000. 2005;37(1):124-37. https://doi.org/10.1111/j.1600-0757.2004.03793.x

28. Johnson GK, Guthmiller JM. The impact of cigarette smoking on periodontal disease and treatment. Periodontol 2000. 2007;44(1):178-94. https://doi.org/10.1111/j.1600-0757.2007.00212.x

29. Wan $C P$, Leung WK, Wong MC, Wong RM, Wan $P$, Lo EC et al. Effects of smoking on healing response to non-surgical periodontal therapy: a multilevel modelling analysis. J Clin Periodontol. 2009;36(3):229-39. https://doi.org/10.1111/j.1600-051X.2008.01371.x

30. KaldahI WB, Kalkwarf KL, Patil KD. A review of longitudinal studies that compared periodontal therapies. J Periodontol. 1993;64(4):243-53. https://doi.org/10.1902/jop.1993.64.4.243

31. Adriaens PA, De Boever JA, Loesche WJ. Bacterial invasion in root cementum and radicular dentin of periodontally diseased teeth in humans. A reservoir of periodontopathic bacteria. J Periodontol. 1988;59(4):222-30. https://doi.org/10.1902/jop.1988.59.4.222

32. Grossi SG, Zambon J, Machtei EE, Schifferle R, Andreana S, Genco RJ et al. Effects of smoking and smoking cessation on healing after mechanical periodontal therapy. J Am Dent Assoc. 1997;128(5):599-607. https://doi.org/10.14219/jada.archive.1997.0259

33. Haffajee AD, Cugini MA, Dibart S, Smith C, Kent RL Jr, Socransky SS. The effect of SRP on the clinical and microbiological parameters of periodontal diseases. J Clin Periodontol. 1997;24(5):324-34. https://doi.org/10.1111/j.1600-051X.1997.tb00765.x

34. Renvert S, Dahlén G, Wikström M. The clinical and microbiological effects of non-surgical periodontal therapy in smokers and non-smokers. J Clin Periodontol. 1998;25(2):15357. https://doi.org/10.1111/j.1600-051X.1998.tb02421.x

35. Cionca N, Giannopoulou C, Ugolotti G, Mombelli A. Microbiologic testing and outcomes of full-mouth scaling and root planing with or without amoxycilin/metronidazole in chronic periodontitis. J Periodontol. 2010;81(1):15-23. https://doi.org/10.1902/jop.2009.090390

36. Silva MP, Feres M, Sirotto TA, Soares GM, Mendes JA, Faveri $M$, et al. Clinical and microbiological benefits of metronidazole alone or with amoxicillin as adjuncts in the treatment of chronic periodontitis: a randomized placebo-controlled clinical trial. J Clin Periodontol. 2011;38(9):828-37. https://doi.org/10.1111/j.1600-051X.2011.01763.x

37. Sgolastra F, Gatto R, Petrucci A, Monaco A. Effectiveness of systemic amoxicillin/metronidazole as adjunctive therapy to scaling and root planing in the treatment of chronic periodontits: a systematic review and meta-analysis. J Periodontol. 2012;83(10):1257-69. https://doi.org/10.1902/jop.2012.110625 
38. Palmer RM, Matthews JP, Wilson RF. Non-surgical periodontal treatment with and without adjunctive metronidazole in smokers and non-smokers.

J Clin Periodontol. 1999;26(3):158-63. https://doi.org/10.1034/j.1600-051X.1999.260305.x

39. Söder B, Nedlich U, Jin LJ. Longitudinal effect of non-surgical treatment and systemic metronidazole for 1 week in smokers and non-smokers with refractory periodontitis: a 5-year study. J Periodontol. 1999;70(7):761-71. https://doi.org/10.1902/jop.1999.70.7.761

40. Mascarenhas P, Gapski R, Al-Shammari K, Hill R, Soehren S, Fenno JC et al. Clinical response of azithromycin as an adjunct to non-surgical periodontal therapy in smokers. J Periodontol. 2005;76(3):426-36. https://doi.org/10.1902/jop.2005.76.3.426

41. Pahkla ER, Koppel T, Naaber P, Saag M, Loivukene K. The efficacy of non-surgical and systemic antibiotic treatment on smoking and non-smoking periodontitis patients. Stomatologija. 2006;8(4):116-21.

42. Dastoor SF, Travan S, Neiva RF, Rayburn LA, Giannobile WV, Wang $\mathrm{HL}$. Effect of adjunctive systemic azithromycin with periodontal surgery in the treatment of chronic periodontitis in smokers: a pilot study. J Periodontol. 2007;78(10):1887-96. https://doi.org/10.1902/jop.2007.070072

43. Needleman I, Suvan J, Gilthorpe MS, Tucker R, St George G, Giannobile W et al. A randomized-controlled trial of low-dose doxycycline for periodontitis in smokers. J Clin Periodontol. 2007;34(4):325-33. https://doi.org/10.1111/j.1600-051X.2007.01058.x

44. Matarazzo F, Figueiredo LC, Cruz SE, Faveri M, Feres M. Clinical and microbiological benefits of systemic metronidazole and amoxicillin in the treatment of smokers with chronic periodontitis: a randomized placebo-controlled study. J Clin Periodontol. 2008;35(10):885-96. https://doi.org/10.1111/j.1600-051X.2008.01304.x

45. Faveri M, Rebello A, de Oliveira Dias R, Borges-Junior I, Duarte PM, Figueiredo LC et al. Clinical and microbiologic effects of adjunctive metronidazole plus amoxicillin in the treatment of generalized chronic periodontitis: smokers versus non-smokers. J Periodontol. 2014;85(4):581-91. https://doi.org/10.1902/jop.2013.130278

46. Higgins JPT, Green S, editors. Cochrane handbook for systematic reviews of interventions Version 5.1.0. The Cochrane Collaboration, 2011 [cited 2012 May 1]. Available from: http://www.cochrane-handbook.org.

47. Moher D, Liberati A, Tetzlaff J, Altman DG;. Preferred reporting items for systematic reviews and meta-analyses: the PRISMA statement. Ann Intern Med. 2009;151(4):264-9. https://doi.org/10.7326/0003-4819-151-4-200908180-00135

48. Jadad AR, Moore RA, Carroll D, Jenkinson C, Reynolds DJ, Gavaghan DJ et al. Assessing the quality of reports of randomized clinical trials: is blinding necessary? Control Clin Trials. 1996;17(1):1-12. https://doi.org/10.1016/0197-2456(95)00134-4 PMID:8721797
49. Sterne JA, Egger M. Funnel plots for detecting bias in meta-analysis: guidelines on choice of axis.. J Clin Epidemiol. 2001;54(10):1046-55. https://doi.org/10.1016/S0895-4356(01)00377-8

50. Egger M, Davey Smith G, Schneider M, Minder C. Bias in meta-analysis detected by a simple, graphical test. BMJ. 1997;315(7109):629-34. https://doi.org/10.1136/bmj.315.7109.629

51. Preus HR, Sandvik L, Gjermo P, Baelum V. Baseline adjustment and change revisited: effect of smoking on change in periodontal status following periodontal therapy. Eur J Oral Sci. 2014;122(2):89-99. https://doi.org/10.1111/eos.12111

52. Socransky SS, Haffajee AD, Cugini MA, Smith C, Kent RL Jr. Microbial complexes in subgingival plaque. J Clin Periodontol. $1998 ; 25(2): 134-44$. https://doi.org/10.1111/j.1600-051X.1998.tb02419.x

53. Chambrone L, Vargas M, Arboleda S, Serna M, Guerrero M, Sousa J et al. Efficacy of local and systemic antimicrobials in the non-surgical treatment of smokers with chronic periodontitis: a systematic review. J Periodontol. 2016;87(11):1320-32. https://doi.org/10.1902/jop.2016.160268

54. Grossi SG, Goodson JM, Gunsolley JC, Otomo-Corgel J, Bland PS, Doherty F et al. Mechanical therapy with adjunctive minocycline microspheres reduces red-complex bacteria in smokers. J Periodontol. 2007;78(9):1741-50. https://doi.org/10.1902/jop.2007.070118

55. Gomi K, Yashima A, Nagano T, Kanazashi M, Maeda N, Arai T. Effects of full-mouth scaling and root planing in conjunction with systemically administered azithromycin. J Periodontol. 2007;78(3):422-9. https://doi.org/10.1902/jop.2007.060247

56. Winkel EG, Van Winkelhoff AJ, Timmerman MF, Van der Velden U, Van der Weijden GA. Amoxicillin plus metronidazole in the treatment of adult periodontitis patients: a double-blind placebo-controlled study. J Clin Periodontol. 2001;28(4):296-305. https://doi.org/10.1034/i.1600-051x.2001.028004296.x

57. Haffajee AD, Torresyap G, Socransky SS. Clinical changes following four different periodontal therapies for the treatment of chronic periodontitis: 1-year results. J Clin Periodontol. 2007;34(3):243-53. https://doi.org/10.1111/j.1600-051X.2006.01040.x

58. Haffajee AD, Patel M, Socransky SS. Microbiological changes associated with four different periodontal therapies for the treatment of chronic periodontitis. Oral Microbiol Immunol. 2008;23(2):148-57. https://doi.org/10.1111/j.1399-302X.2007.00403.x

59. Rooney J, Wade WG, Sprague SV, Newcombe RG, Addy M. Adjunctive effects to non-surgical periodontal therapy of systemic metronidazole and amoxicillin alone and combined: a placebo controlled study. J Clin Periodontol. 2002;29(4):342-50. https://doi.org/10.1034/i.1600-051X.2002.290410.x 
- Antibiotic therapy as an adjunct to scaling and root planing in smokers: a systematic review and meta-analysis

60. Sgolastra F, Severino M, Petrucci A, Gatto R, Monaco A. Effectiveness of metronidazole as an adjunct to scaling and root planing in the treatment of chronic periodontitis: a systematic review and meta-analysis. J Periodontal Res. 2014;49(1):10-9. https://doi.org/10.1111/jre.12089

61. Mombelli A, Almaghlouth A, Cionca N, Courvoisier DS, Giannopoulou C. Differential benefits of amoxicillin-metronidazole in different phases of periodontal therapy in a randomized controlled crossover clinical trial. J Periodontol.

2015;86(3):367-75. https://doi.org/10.1902/jop.2014.140478

62. Mombelli A. Heresy? Treatment of chronic periodontitis with systemic antibiotics only. J Clin Periodontol. 2006;33(9):661-2.

https://doi.org/10.1111/j.1600-051X.2006.00976.x 